\title{
A late Maastrichtian selachian assemblage from the Peedee Formation of North Carolina, USA
}

\section{Gerard R. Case ${ }^{1}$, Todd D. Cook ${ }^{\star, 2}$, Eric M. Sadorf ${ }^{3}$ and Kevin R. Shannon ${ }^{4}$}

${ }^{1}$ P.O. Box 664, Little River, SC 29566, USA, fosshark@sccoast.net

${ }^{2}$ School of Science, Penn State Behrend, 4205 College Drive, Erie, PA 16563, USA, tdc15@psu.edu

${ }^{3}$ Hemlock Street, Cary, NC 27513, USA, emsadorf@usgs.gov

${ }^{4} 4137$ Sunset Drive, Martinsvile, VA 24112, USA, iontase@hotmail.com

\begin{abstract}
A diverse selachian fauna was collected from the Island Creek Member of the Peedee Formation at Castle Hayne, New Hanover County, North Carolina, USA. This inner neritic assemblage consists of 23 species from 20 genera, 17 families and eight orders and includes the new species Ptychotrygon clementsi sp. nov. The dentitions of a few, large, macrophagous species with large palaeobiogeographical ranges is described. However, the majority of the reported specimens belong to relatively small species that are endemic to the southern regions of the Western Interior Seaway and the Atlantic and Gulf Coastal plains of North America.
\end{abstract}

Key Words: Late Cretaceous, Elasmobranchii, palaeoecology, palaeobiogeography LSID: urn:lsid:zoobank.org:pub:290FC1C3-E74D-438C-9E28-B1BE662988AA

\section{INTRODUCTION}

The Atlantic and Gulf coastal plains of the United States have many Late Cretaceous and Palaeogene marine deposits that are rich in selachian (shark and ray) material (e.g., Ward and Wiest 1990; Kent 1994; Case 1981, 1994; Parmley and Cicimurri 2003; Cicimurri 2007; Case et al. 2015). Herein, we describe an assemblage recovered from the late Maastrichtian Island Creek Member of the Peedee Formation at Castle Hayne, New Hanover County, North Carolina. Case (1979) previously described 11 euselachian taxa from this formation in Duplin County, North Carolina. The majority of the recovered species were rather large macrophagous sharks with relatively large palaeobiogeographical ranges; only two batoids were reported. In addition to presenting a new Ptychotrygon species, the purpose of this study is to augment the faunal list of selachians that are found in this particular geological unit and to elucidate palaeobiogeographical extensions.

\section{GEOLOGY}

All specimens were recovered from the late Maastrichtian Island Creek Member of the Peedee Formation. The Island

\section{* corresponding author}

Published April 26, 2017

(c) 2017 by the authors

submitted Nov. 11, 2016; revisions received April 20, 2017;

accepted April 24 2017. Handling editor: Alison Murray.
Creek Member of the Peedee Formation was described by Dockal et al. (1998, p.158) as an "olive gray, well sorted, very fine to fine grained, poorly indurated, bioturbated, argillaceous, dolomitic quartz wacke". It is found in Brunswick, New Hanover, Pender and Onslow Counties in North Carolina and reaches a thickness of almost 15 meters (Dockal et al. 1998). At this locality the Island Creek Member rests on the Rocky Point Member of the Peedee Formation and is overlain by the late middle to early late Eocene Castle Hayne Formation.

The Island Creek Member in the Martin-Marietta Castle Hayne Quarry has variable thickness and a tendency to pinch out over short distances. The quarry exposure where the bulk samples were collected has an exposed thickness of approximately $2 \mathrm{~m}$. The upper few centimeters are heavily burrowed and infilled with material from the overlying Castle Hayne Formation. Selachian material is sparse in the lower $1.5 \mathrm{~m}$ of this exposure and more concentrated in the upper $0.4 \mathrm{~m}$ in an area between a discontinuous, mostly disarticulated layer of Exogyra shells and the base of the Castle Hayne Formation.

The Island Creek Member represents an inner neritic environment of normal salinity (Dockal et al. 1998; Harris and Self-Trail 2006). An age of 66.9 Ma was reported, based on $87 \mathrm{Sr} / 86 \mathrm{Sr}$ isotopic analysis performed on the cuticle of a well-preserved crab Ophthalmoplax brasiliana (Vega et al. 2013). 


\section{METHODS AND MATERIALS}

The dentition was recovered from a quarry exposure within the Martin-Marietta Aggregate, Castle Hayne Quarry (Fig. 1) located in New Hanover County, North Carolina (34 $22^{\prime} 30^{\prime}$ N, 770 50' 6" W). The majority of the specimens were collected by bulk sampling using a U.S. Standard Sieve Series No. 30 (530 microns/0.0234 in opening). Some of the larger teeth were surface collected from spoil piles within the quarry. Adhering matrix was removed using buffered $10 \%$ acetic acid solution. Smaller teeth were imaged using a Jeol Field Emission Scanning Electron Microscope (JSM$6301 \mathrm{FXV}$ ), whereas larger teeth were coating in ammonium chloride and imaged using a Nikon DXM 1200c digital camera mounted on a Zeiss Discovery V8 stereomicroscope. The material is catalogued in the collections of the University of Alberta Laboratory for Vertebrate Palaeontology

(UALVP). Dental terminology and taxonomy largely follows that of Cappetta (2012).

\section{SYSTEMATIC PALAEONTOLOGY}

Class CHONDRICHTHYES Huxley, 1880

Subclass ELASMOBRANCHII Bonaparte, 1838

Cohort EUSELACHII Hay, 1902

Division NEOSELACHII Compagno, 1977

Superorder SQUALIMORPHII Compagno, 1973
Order HEXANCHIFORMES Buen, 1926

Family HEXANCHIDAE Gray, 1851

Genus Notidanodon Cappetta, 1975a

Notidanodon sp.

Figure $2 \mathrm{~A}$ and $\mathrm{B}$

Referred Material: UALVP 57015, incomplete upper anterolateral tooth; UALVP 57016, incomplete lower lateral tooth.

Description: The fractured upper anterior tooth with a relatively large distally inclined median cusp (= acrocone) is partially damaged. The mesial cutting edge bears three small distally inclined cusplets. The upper two-thirds of the distal cutting edge is more or less straight, whereas the basal one-third is concave. A smaller distally inclined cusp (= accessory cone) follows the median cusp. The labial and lingual faces of the poorly preserved root are high and bear a strong lingual protuberance. Both root faces bear multiple foramina.

The fractured lower lateral tooth is missing the median cusp but has preserved six distally inclined cusps of decreasing size. Both cusp cutting edges are very slightly convex. The root is incomplete. The labial root face is flat, whereas the lingual face contains a well-developed budge. Both faces possess multiple foramina.

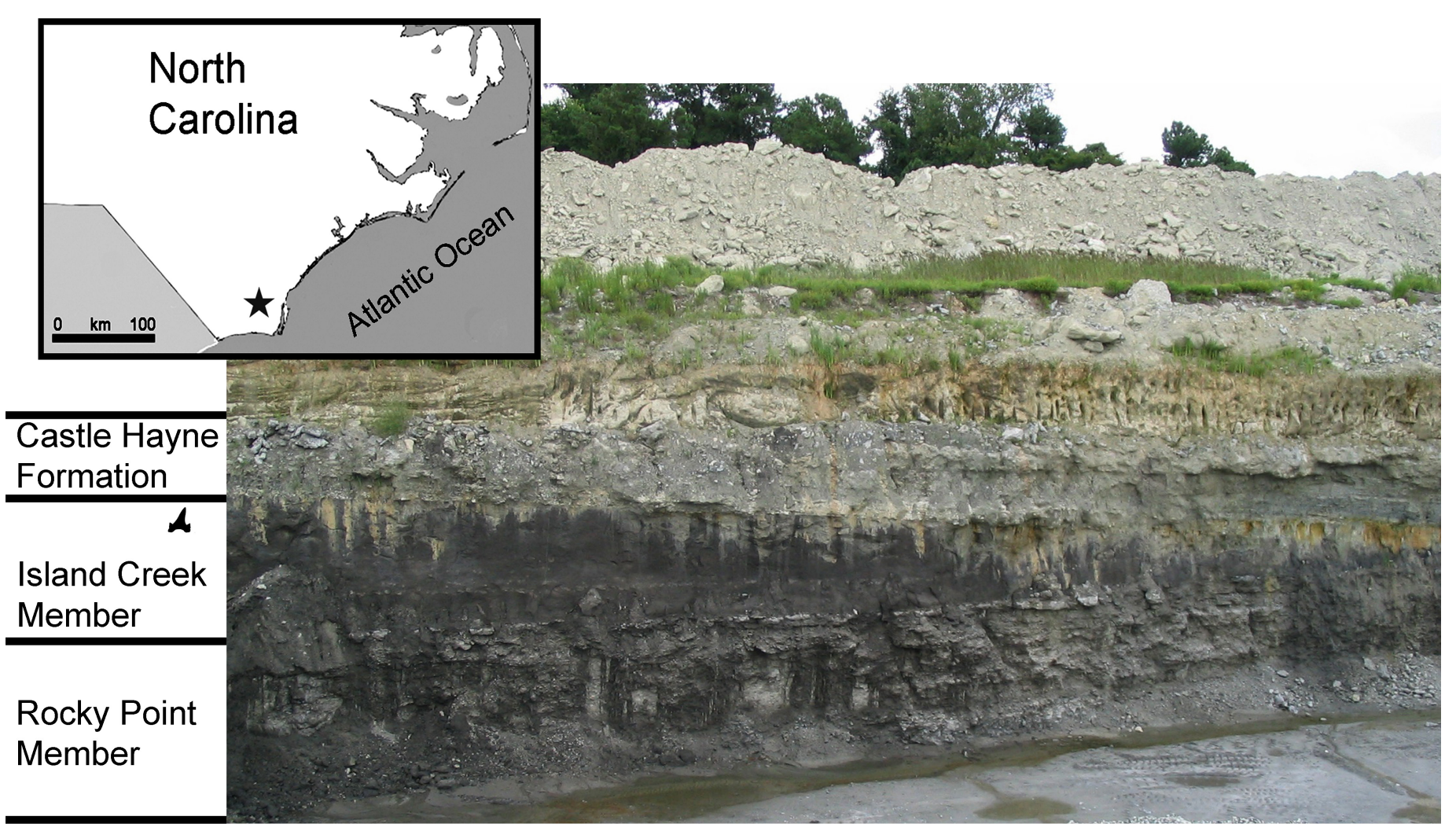

Figure 1. Map and stratigraphy of the Martin-Marietta Castle Hayne Quarry. Note the Island Creek Member pinches out to the right in this image. Silhouette of shark tooth represents fossil occurrence within the upper $0.4 \mathrm{~m}$ of the deposit. 
Remarks: Cappetta (2012) noted that the lower lateral teeth of Notidanodon can reach up to $6 \mathrm{~cm}$ in width. The relatively small size of the teeth described herein indicates that they likely belonged to a juvenile individual.

Late Cretaceous reports of Notidanodon include $N$. dentatus (Woodward, 1886), from New Zealand (Woodward 1886; Davis 1888), Antarctica (Martin and Crame 2006), and South America (Bogan et al. 2016), and N. pectinatus from Europe (Agassiz 1843; Woodward 1886), New Zealand (Adolfssen and Ward 2014), Antarctica (Cione and Medina 1987 ) and the west coast of North America (Applegate 1965). Adolfssen and Ward (2014) noted that the mesial cusplets are clearly separated and more erect in the latter species. The Peedee specimens have an overall morphology similar to that of $N$. dentatus; however, given the poor preservation, we conservatively leave this specimen in open nomenclature. It should be noted that it is the first occurrence of Notidanodon from the east coast of North America.

\section{Order SQUALIFORMES Goodrich, 1909 \\ Family SQUALIDAE Bonaparte, 1834 \\ Genus Squalus Linnaeus, 1758 \\ Squalus huntensis Case and Cappetta, 1997}

Figure 2C

Referred Material: UALVP 57017, complete tooth. Description: This is a small tooth with a median cusp that is strongly distally inclined. The basal one-third of the mesial cutting edge is convex, whereas the remaining apical two-thirds is more or less straight. The distal cutting edge is considerably smaller and is also relatively straight. The distal heel is high and well-developed. The labial crown face is smooth and has a narrow and elongated apron that extends well below the basal edge of the root. The lingual crown face is also smooth and bears a distinct uvula. The low root has a flat basal face and a large central foramen. Multiple smaller foramina are situated along the labial root face.

Remarks: This species was first reported from the late Maastrichtian Kemp Formation of Texas (Case and Cappetta 1997). Teeth reported by Welton and Farish (1993) as Squalus sp. from the same formation is likely conspecific. The Peedee specimen represents only the occurrence of this species outside of Texas.

Superorder GALEOMORPHII Compagno, 1973 Order HETERODONTIFORMES Berg, 1937 Family HETERODONTIDAE Gray, 1851 Genus Heterodontus Blainville, 1816 Heterodontus granti Case and Cappetta, 1997 Figure $2 \mathrm{D}$ and $\mathrm{E}$
Referred Material: UALVP 57018, complete anterior tooth; UALVP 57019, complete lateral tooth of unknown jaw position.

Description: The anterior tooth has a median cusp that is flanked by two pairs of divergent lateral cusplets. Both crown faces are smooth but the enameloid of the apron is slightly damaged. The basal edge of the apron is straight and overhangs the root. The latter is considerably damaged but the remains indicate that the root lobes are V-shaped in basal view.

The lateral tooth is mesodistally elongated. The crown is slightly convex and divided into labial and lingual faces by a transverse ridge. Both faces have enameloid folding that run perpendicular to this ridge. The crown overhangs the root. Both labial and lingual root faces possess large and smaller foramina. The basal face is more or less flat.

Remarks: The Peedee specimens represent the second known occurrence of Heterodontus granti and the first report of a lateral tooth from this species. This taxon was erected based on anterior and anterolateral teeth from the late Maastrichtian Kemp Clay Formation of Texas (Case and Cappetta 1997).

Order ORECTOLOBIFORMES Applegate, 1972 Family GINGLYMOSTOMATIDAE Gill, 1862 Genus Cantioscyllium Woodward, 1889 Cantioscyllium cf. C. meyeri Case and Cappetta, 1997 Figure $2 \mathrm{~F}$

Referred Material: UALVP 57020, incomplete tooth. Description: The anterolateral tooth has a tall median cusp that is flanked by a pair of poorly developed lateral cusplets. Distal to the lateral cusplets is a second incipient pair. The labial crown face has weak striations that extend to the apex but are more concentrated on the basal half of the median cusp. The apron overhangs the labial root face and has a medially positioned concavity. The lingual crown face is smooth and has a distinct medio-lingual protuberance. The root is low and slightly damaged. The root lobes are V-shaped in basal view and a large central foramen is present.

Remarks: Cantioscyllium meyeri was first reported from late Maastrichtian Kemp Clay Formation of Texas (Case and Cappetta, 1997) and subsequently reported from the early Campanian Taylor Marl Formation (Cappetta and Case, 1999). Teeth of C. saginatus (Meyer, 1974) are likely conspecific with that of $C$. meyeri (Cappetta and Case, 1999). The overall morphology of the Peedee tooth is similar to the latter; however, the enameloid folding of the labial crown face is considerably weaker than that of the type material. As such, we conservatively noted that the specimen conforms favourably to C. meyeri. 


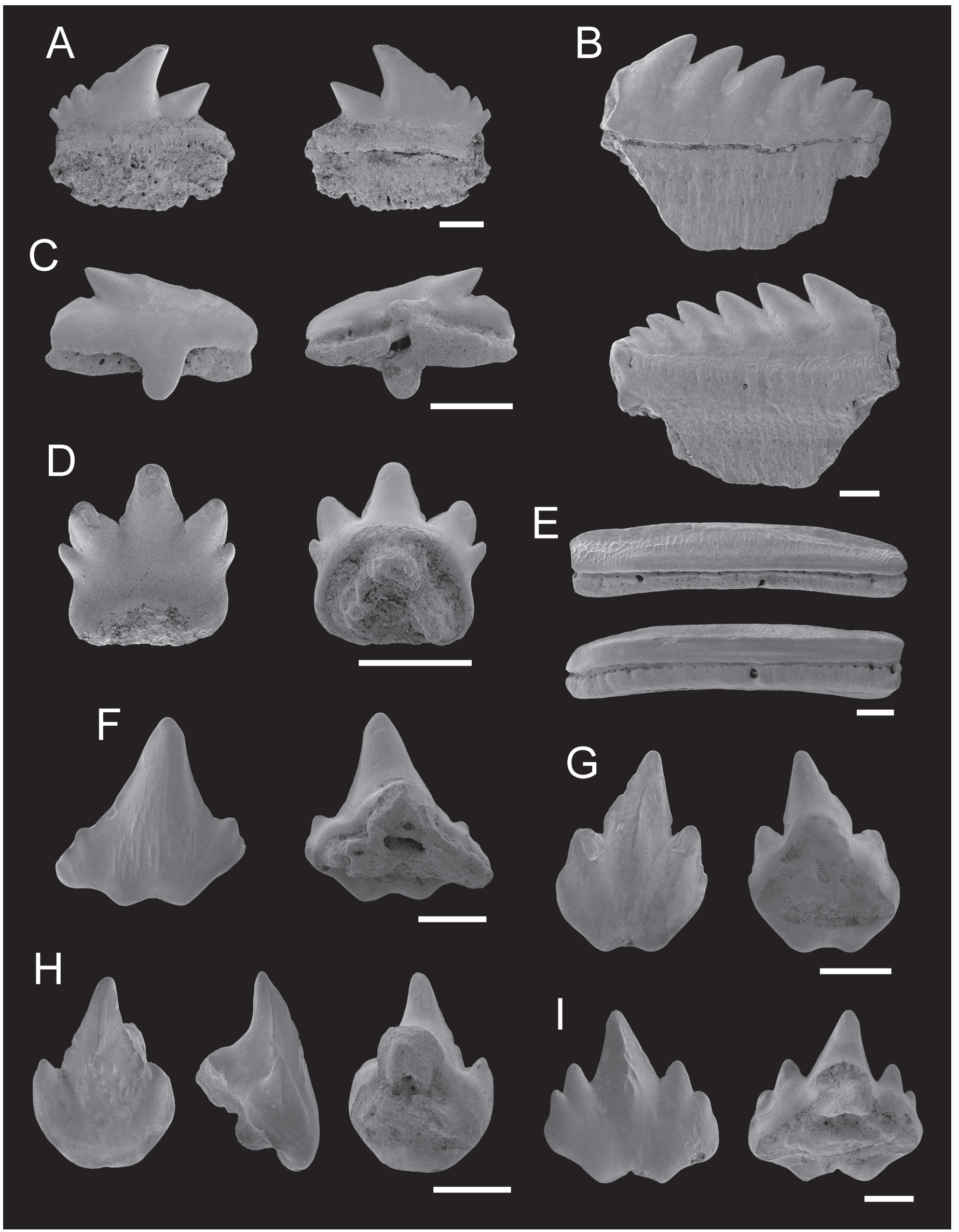


Genus Plicatoscyllium Case and Cappetta, 1997

Plicatoscyllium antiquum Case and Cappetta, 1997

Figure $2 \mathrm{G}$ and $\mathrm{H}$

Referred Material: UALVP 57021, incomplete tooth; UALVP 57022, incomplete tooth of indeterminate jaw position.

Description: The anterior teeth have a tall median cusp that is lingually directed. The cusp is distinctly separated from a pair of slightly divergent lateral cusplets. The upper region of the labial crown face bears strong labial crest. The relatively wide apron overhangs the labial root face and has a basal edge that is rounded or is concave medially. The lingual crown face is smooth and contains a well-developed medio-lingual protuberance. The root is poorly preserved but appears to have V-shaped root lobes and a large central foramen in basal view.

Remarks: This species was first reported from the late Maastrichtian Kemp Clay Formation of Texas (Case and Cappetta 1997). Antunes and Cappetta (2002) reported teeth of similar morphology from the late Campanian/early Maastrichtian of Angola; however, they did note slight differences including smaller lateral cusplets, an apron that is wider and less prominent, and a less distinct labial crown crest than the type material.

\section{Plicatoscyllium derameei Case and Cappetta, 1997} Figure 2I

Referred Material: UALVP57023, incomplete tooth of indeterminate jaw position.

Description: The anterior tooth has a median cusp that is lingually directed and flanked by two pairs of slightly divergent lateral cusplets. The labial crown face bears labial crest that becomes braided at its base. The apron overhangs the labial root face and its basal edge is concave medially. The smooth lingual crown face has a well-developed medio-lingual protuberance. The root is considerably damaged but the central foramen is preserved.

Remarks: First reported from the late Maastrichtian Kemp Clay Formation of Texas, Case and Cappetta
(1997) distinguished this species from P. antiquum (Case and Cappetta, 1997) by its larger overall size, taller median cusp, multiple pairs of lateral cusplets, and its salient apron that has a basal edge that is more concave medially. These characters are clearly identified in the Peedee tooth. Becker et al. (2006) also reported this species from the late Maastrichtian Arkadelphia Formation of Arkansas.

\section{Order LAMNIFORMES Berg, 1958 \\ Family MITSUKURINIDAE Jordan, 1898 \\ Genus Anomotodon Arambourg, 1952 \\ Anomotodon cf. A. toddi Case and Cappetta, 1997}

Figure 3A

Referred Material: UALVP 57024, complete lateral tooth.

Description: This tooth has a tall triangular median cusp that is distally inclined and flanked by a pair of rounded distal heels. The slightly damaged labial crown face is mostly smooth with only a few very weak enameloid folds situated along the base medially. The labial basal edge overhangs the root. The lingual face is completely smooth and convex. A distinct cutting edge runs continuously across the cusp and cusplets. The root is somewhat eroded. The lingual protuberance has a nutrient groove that bears foramina. A shallow U-shaped basal concavity separates the asymmetrical root lobes. The mesial lobe is elongated and rounded, whereas the distal lobe is more angular.

Remarks: The lack of lingual enameloid folding distinguishes this species from other Anomotodon taxa (Case and Cappetta 1997). The only previous reports of $A$. toddi are from the Campanian (Welton and Farish 1993, as Paranomotodon sp.) and late Maastrichtian of Texas (Case and Cappetta 1997). Mustafa (2000) reported this species from the late Santonian of Jordan. The single recovered tooth also lacks any lingual striations; however, the crown heels appear less developed and the root is more gracile and possesses rounded root lobes. As such, the Jordanian (Mustafa 2000) specimens likely represent a separate but closely related species. We cautiously assign the Peedee specimen as Anomotodon cf. A. toddi because of the slightly eroded nature of the root.

\section{$\leftarrow$ Opposite Page}

Figure 2. Hexanchiform, squaliform, heterodontiform, and orectolobiform teeth recovered from the late Maastrichtian Peedee Formation at Castle Hayne, New Hanover County, North Carolina. A, Notidanodon sp., UALVP 57015 (incomplete upper anterolateral tooth); B, Notidanodon sp., UALVP 57016 (incomplete lower lateral tooth); C, Squalus huntensis Case and Cappetta, 1997, UALVP 57017 (complete tooth); D, Heterodontus granti Case and Cappetta, 1997, UALVP 57018 (complete anterior tooth); E, H. granti UALVP 57019 (complete lateral tooth); F, Cantioscyllium cf. C. meyeri Case and Cappetta, 1997, UALVP 57020 (incomplete tooth); G, Plicatoscyllium antiquum Case and Cappetta, 1997, UALVP 57021 (incomplete tooth); H, P. antiquum, UALVP 57022 (incomplete tooth); I, Plicatoscyllium derameei Case and Cappetta, 1997, UALVP 57023 (incomplete tooth). Views: labial (left) and lingual (right) for A, C, D, F, G, and I; labial (top) and lingual (bottom) for B; labial (left), profile (center), and lingual (right) for H. Scale bars $=1 \mathrm{~mm}$. 


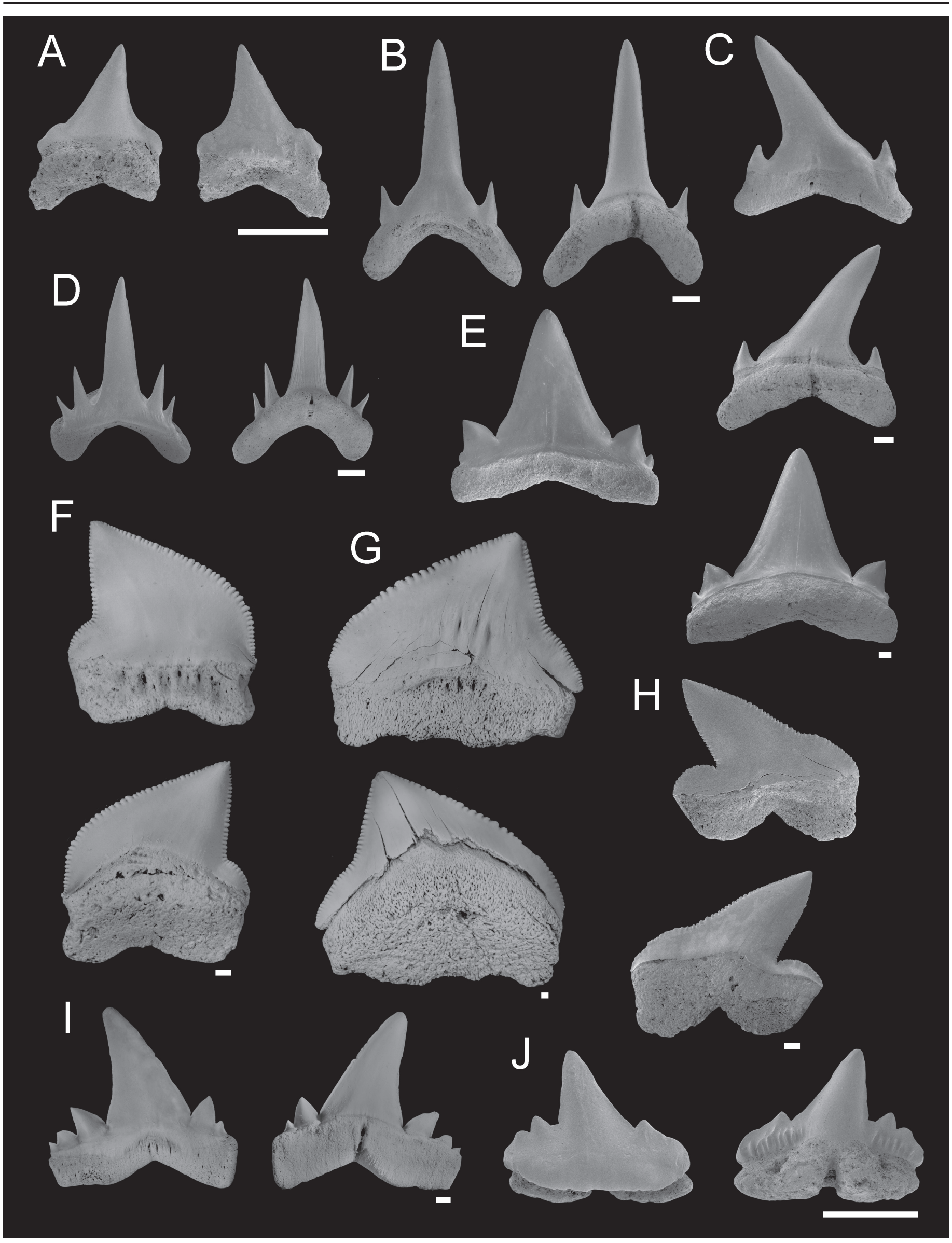


Family ODONTASPIDIDAE Müller \& Henle, 1839

Genus Carcharias Rafinesque, 1810

Carcharias cf. C. samhammeri Cappetta and Case, 1975

Figure $3 \mathrm{~B}$ and $\mathrm{C}$

Referred Material: UALVP 57025, complete lower anterior tooth; UALVP 57026, complete upper lateral tooth.

Description: The anterior tooth has a narrow and erect median cusp that is slightly lingually directed. The labial crown face is slightly convex and overhangs the labial root face. The lingual crown face is strongly convex. Both crown faces are completely devoid of any enameloid folding. A distinct cutting edge runs continuously across the cusp and a pair of well-developed lateral cusplets. A narrow lingual neck is present. The lingual protuberance bears a strong nutrient groove. A deep 'U-shaped' basal concavity separates the elongated root lobes.

The lateral tooth has a distally inclined median cusp that is flanked by a pair of small erect lateral cusplets. The smooth labial face slightly overhangs the root and is more or less flat, whereas the smooth lingual face is convex. The lingual neck is narrow. The lingual protuberance possesses a distinct nutrient groove and central foramen. The relatively shallow and V-shaped basal concavity separated the root lobes. Both root faces have additional foramina.

Remarks: Carcharias samhammeri was originally described from the early Maastrichtian of New Jersey (Cappetta and Case 1975). Subsequently, this species has also been reported from Western Interior Seaway late Maastrichtian deposits of South Dakota (Becker et al. 2004, as Carcharias cf. C. samhammeri) and Texas (Case and Cappetta 1997, as Carcharias cf. C. sambammeri). The single tooth described from the latter deposit closely resembles the lateral Peedee specimen. The gracile nature of both of these teeth, relatively to that of the type material, may be the result of ontogenetic variation (Case and Cappetta 1997).

Genus Odontaspis Agassiz, 1838 Odontaspis aculeatus Cappetta and Case, 1975

Figure 3D
Referred Material: UALVP 57027, complete lower anterior tooth.

Description: This tooth has an erect median cusp flanked by two pairs of large lateral cusplets. The labial crown face is flat and overhangs the root. Short enameloid folds are present along the base of the labial face. The lingual crown face is convex and bears distinct striation that extends over one-half of the height of the median cusp and lateral cusplets. The cutting edge is distinct and runs continuously across the cusp and cusplets. The lingual neck is narrow. The lingual protuberance is well-developed and contains two central foramina. The basal concavity is U-shaped and separated root lobes that are somewhat labiolingually compressed. Small foramina are present throughout both root faces.

Remarks: Odontaspis aculeatus was original described from the late Campanian of New Jersey (Cappetta and Case 1975) and subsequently reported from late Campanian to late Maastrichtian deposits of the Severn, Marshalltown and Mount Laurel formations of the Chesapeake Bay region (Lauginiger and Hartstein 1983; Hartstein et al. 1999; Kent 1994). From the Gulf coastal plain, this species was reported from the late Maastrichtian Arkadelphia Formation of Arkansas (Becker et al. 2006). Within the Western Interior Seaway, this species has been reported from the late Campanian Dinosaur Park Formation of Alberta (Beavan and Russell 1999), the late Maastrichtian Fox Hills Formation of South Dakota (Becker et al. 2004) and the late Maastrichtian Kemp Clay Formation of Texas (Case and Cappetta 1975).

$$
\begin{gathered}
\text { Family OTODONTIDAE Glikman, } 1964 \\
\text { Genus Cretalamna Glikman, } 1958 \\
\text { Cretalamna maroccana (Arambourg, 1935) }
\end{gathered}
$$

Figure 3E

Referred Material: UALVP 57028, complete lateral tooth. Description: This tooth has a broad triangular median cusp that is flanked by two pairs of lateral cusplets. The medially positioned cusplets are large and well-developed, whereas the laterally positioned pair are incipient. The

\section{$\leftarrow$ Opposite Page}

Figure 3. Lamniform and carcharhiniform teeth recovered from the late Maastrichtian Peedee Formation at Castle Hayne, New Hanover County, North Carolina. A, Anomotodon cf. A. toddi Case and Cappetta, 1997, UALVP 57024 (complete tooth); B, Carcharias cf. C. samhammeri Cappetta and Case, 1975, UALVP 57025 (complete anterior tooth); C, Carcharias cf. C. samhammeri, UALVP 57026 (complete lateral tooth); D, Odontaspis aculeatus Cappetta and Case, 1975, UALVP 57027 (complete anterior tooth); E, Cretalamna maroccana (Arambourg, 1935), UALVP 57028 (complete tooth); F, Squalicorax kaupi (Agassiz, 1843), UALVP 57029 (complete tooth); G, Squalicorax pristodontus (Agassiz, 1843), UALVP 57030 (incomplete tooth); H, Pseudocorax cf. P. affinis (Münster in Agassiz, 1843), UALVP 57031 (complete tooth); I, Serratolamna serrata (Agassiz, 1843), UALVP 57032 (complete tooth); J, Palaeogaleus sp., UALVP 57033 (complete tooth). Views: labial (left) and lingual (right) for A, B, D, E, I, and J; labial (top) and lingual (bottom) for C, F, G, and H. Scale bars $=1 \mathrm{~mm}$. 
smooth labial crown face is more or less flat. The lingual face is also smooth but convex. A distinct cutting edge runs continuously across the median cusp and lateral cusplets. The lingual neck is narrow. The lingual protuberance bears two foramina. A shallow basal concavity separates rectangular-shaped root lobes.

Remarks: This cosmopolitan species has been reported from northern and western Africa (e.g., Arambourg 1935, 1952; Dartevelle and Casier 1959; Antunes 1964; Cappetta et al. 2014), Madagascar (Gottfried et al. 2001) and the Middle East (Bardet et al. 2000). In North America, C. maroccana was reported from late Maastrichtian of Texas (Welton and Farish 1993: p.112, fig. 6, as Serratolamna serrata; Case and Cappetta 1997) and the Chesapeake Bay region (Kent 1994, as C. biauriculata maroccana). Teeth previously reported from the Peedee Formation of Duplin County, North Carolina by Case (1979) as C. biauriculata show an overall morphology more akin to that of $C$. marocanna.

\section{Family ANACORACIDAE Casier, 1947 Genus Squalicorax Whitley, 1939 Squalicorax kaupi (Agassiz, 1843)}

Figure $3 \mathrm{~F}$

Referred Material: UALVP 57029, complete lateral tooth. Description: This tooth has a large distally inclined median cusp. The labial crown face is flat, whereas the lingual face is convex. The basal one-half of the mesial cutting edge is strongly convex, whereas the apical $2 / 3$ is more-orless straight. The distal cutting edge is relatively straight and vertical. The distal heel forms an obtuse angle with the distal cutting edge. The cutting edges of the median cusp bear simple serrations that decrease in size towards the apex and crown base. The serrations run continuously over the distal heel. A lingual band is present but is somewhat eroded. The root is high with a weak lingual protuberance that lacks a nutrient groove. The root lobes are slightly asymmetrical with the distal lobe being slightly more robust. The basal concavity is shallow. Both the labial and lingual root faces contain various sized foramina.

Remarks: Squalicorax kaupi is a cosmopolitan taxon that has been reported from Coniacian to Maastrichtian deposit of Europe, the Middle East, and Africa (Cappetta 2012; Corral et al. 2016 and references therein). In North America, this species has been reported from the southern regions of the Western Interior Seaway (Welton and Farish 1993; Case and Cappetta 1997; Cappetta and Case 1999; Shimada and Cicimurri 2006) and the Gulf Coast Plain (Becker et al. 2006). This species was pre- viously reported from the Peedee Formation of Duplin County, North Carolina (Case 1979). In addition to the Peedee specimens described from this formation, Atlantic Coastal Plain reports of $S$. kaupi also include Campanian and Maastrichtian of New Jersey (e.g., Cappetta and Case 1975; Case et al. 2001).

It should be noted that in their description of Squalicorax cf. S. lindstromi (Davis, 1890) from the Santonian Hosta Tongue of the Point Lookout Sandstone of New Mexico, Bourdon et al (2011, p. 15) considered S. kaupi as being a "suite of similar taxa that have typically been lumped under a single name." Until a complete review of this species is undertaken, we conservatively assign the Peedee teeth to $S$. kaupi.

Squalicorax pristodontus (Agassiz, 1843)

Figure 3G

Referred Material: UALVP 57030, incomplete lateral tooth. Description: This is a large tooth with a distally inclined median cusp. The labial crown face is flat but has multiple shallow grooves medially above the crown-root boundary. The lingual crown face is convex and is considerably damaged basally. The basal one-half of the mesial cutting edge is strongly convex, whereas the apical $2 / 3$ is more-or-less straight. The distal cutting edge is relatively straight and oblique. The distal heel is only slightly differentiated from the distal cutting edge. The irregular serrations run continuously over the median cusp and distal heel.

The root is high with a weak lingual protuberance that bears a large nutrient foramen. The root lobes are damaged but appear to be asymmetrical. The labial root faces contain a number of large foramina medially. Both faces have additional smaller foramina.

Remarks: Squalicorax pristodontus has a widespread palaeobiogeographical distribution that includes Europe, the Middle East, Africa, and South America (Cappetta 2012; Cuny et al. 2012; Corral et al. 2016 and references therein). North American reports include the southern Western Interior Seaway (Welton and Farish 1993; Shimada and Cicimurri 2006) and New Jersey (Cappetta and Case 1975). A single tooth of $S$. pristodontus was also reported from the Peedee Formation of Duplin County, North Carolina (Case 1979).

Teeth of the species can be differentiated from that of $S$. kaupi by having a less acute median cusp apex and less distinct distal heel, possessing more irregular serrations, having a higher root, and being larger in overall size (Welton and Farish 1993; Becker et al. 2006; Cappetta 2012; Corral et al 2016). These characters are readily apparently in the Peedee specimen. 
Family PSEUDOCORACIDAE Cappetta, 2012

Genus Pseudocorax Priem, 1897

Pseudocorax cf. P. affinis (Münster in Agassiz, 1843)

Figure $3 \mathrm{H}$

Referred Material: UALVP 57031, complete tooth. Description: This tooth has a distally inclined median cusp. The labial crown face is flat and slightly overhangs the labial root face. The lingual crown face is convex. The sigmoid mesial cutting edge bears irregular serrations that are poorly developed towards the apex and base. The distal cutting edge is convex and separated from a distal heel by a distinct notch. Well-developed serrations run continuously across the distal cutting edge and heel. The lingual protuberance has two large foramina and lacks a distinct nutrient groove. The asymmetrical root lobes are separated by a relatively deep basal concave.

Remarks: Pseudocorax affinis has been reported from Campanian and Maastrichtian deposits of Europe, the Middle East, and northern Africa (e.g., Woodward 1911; Arambourg 1952; Albers and Weilier 1964; Herman 1977; Lewy and Cappetta 1989; Noubhani and Cappetta 1997; Cappetta and Odin 2001; Adolfssen and Ward 2014). Case and Cappetta (2004) described teeth identified as Pseudocorax aff. P. affinis from the early Maastrichtian Navesink Formation of New Jersey.

The overall tooth morphology of the Peedee specimen closely resembles that of $P$. affinis. However, we cautiously assign this tooth to Pseudocorax cf. P. affinis because it lacks a distinct nutrient groove that is characteristic of this species.

Family SERRATOLAMNIDAE Landemaine, 1991 Genus Serratolamna Landemaine, 1991 Serratolamna serrata (Agassiz, 1843) Figure 3I

Referred Material: UALVP 57032, complete upper lateral tooth.

Description: This tooth is comprised of tall medial cusp that is distally inclined and flanked by two erect lateral cusplets medially and three divergent cusplets distally. The smooth labial crown face is more or less flat and has a sigmoid basal edge. The lingual face is smooth and convex. A distinct cutting edge runs continuously across the cusp and cusplets. The lingual protuberance has a distinct nutrient groove containing a large foramen. The labial root face has numerous small foramina and larger elongated foramina situated in the medial region. A shallow V-shaped basal concavity separates the asymmetrical root lobes. The rectangular-shaped distal lobe is considerably larger than that of the mesial root lobe.
Remarks: Serratolamna serrata is a widely distributed taxon that appears to be restricted to Maastrichtian deposits (Underwood and Mitchell, 2000). This species has been reported from Europe, the Middle East, northern and western Africa, Madagascar, and South America (e.g., Gottfried et al. 2001; Cappetta 2012; Corral et al. 2016 and references therein). From North American deposits, this species has been reported throughout the Western Interior Seaway (e.g., Welton and Farish 1993; Case and Cappetta 1997; Hoganson and Murphy 2002; Becker et al. 2004; Shimada and Brereton 2007) and the Gulf Coast Plain (Becker et al. 2006). Along the Atlantic Coastal Plain, S. serrata was reported from New Jersey (Case 1995; Case et al. 2001) and the Chesapeake Bay region (Kent 1994). Case (1979) previously reported its teeth from the Peedee Formation of Duplin County, North Carolina.

\section{Order CARCHARHINIFORMES Compagno, 1973 Family TRIAKIDAE Gray, 1851 Genus Palaeogaleus Gurr, 1962 Palaeogaleus sp.} Figure 3J

Referred Material: UALVP 57033, complete tooth. Description: This tooth has a triangular median cusp that is distally inclined. The mesial heel bears a single lateral cusplet, whereas the distal heel has two cusplets and flanked by a pair of rounded distal heels. The labial crown face overhangs the root and is mostly smooth with the exception of a few very weak enameloid folds situated under the distal-most lateral cusplet. The lingual crown face has strong enameloid folding along the basal region of the mesial and distal heels. The root is mesiodistally elongated. The nutrient groove completely divides the lingual protuberance and root lobes which have a flat basal face. A central foramen and margino-lingual foramina are present.

Remarks: The morphology of the Peedee specimen is somewhat similar to the Campanian - Maastrichtian species Palaeogaleus faujasi (van de Geyn, 1937) from Europe and Palaeogaleus navarroensis Case and Cappetta 1997 from the late Maastrichtian of Texas (Cappetta 2012). A tooth described as Palaeogaleus sp. from the late Maastrichtian Fox Hills Formation of South Dakota by Becker et al. (2004) is also bears some resemblance to the Peedee tooth. However, unlike the dentition of these species, the tooth described herein possesses strong labial crown enameloid folding. In their report of P. havreensis Herman 1977 from the Campanian of England, Underwood and Ward (2008) noted that the presence of strong ornamentation in the teeth of this taxon likely represents upper dentition, whereas weak ornamentation likely represents lower jaw dentition. 
Consequently, the difference in ornamentation of between the Peedee specimen and the other contemporaneous species may simply be due to dignathic hetereodonty. We therefore, conservatively leave this tooth in open nomenclature.

Superorder BATOMORPHII Cappetta, 1980

Order RAJIFORMES Berg, 1937

Family RHINOBATIDAE Müller and Henle, 1838

Genus Rhinobatos Linck, 1790

Rhinobatos sp.

Figure 4A

Referred Material: UALVP 57034, incomplete tooth of indeterminate jaw position.

Description: This is a small tooth with a non-cuspidate and smooth crown. The labial crown edge is rounded and convex, whereas the lingual crown edge has an elongated median uvula that is flanked by a pair of less-developed lateral uvulae. The root is completely missing.

Remarks: Given the poorly preserved nature of this tooth and the conservative nature of rhinobatoid tooth morphology (see Kriwet 1999; Kriwet et al. 2009; Cappetta 2012), we tentatively identify this specimen as Rhinobatos sp.

Family RAJIDAE Blainville, 1816

Genus Raja Linnaeus, 1758

Raja farishi Case and Cappetta, 1997

Figure 4B

Referred Material: UALVP 57035, complete tooth of indeterminate jaw position.

Description: These teeth have a crown that contains a tall lingually-directed median cusp. The crown faces are smooth and separated by distinct transverse edge. The apron overhangs the labial root face and has a medially positioned convex protuberance. The lingual crown face has a distinct medio-lingual protuberance. The root is constricted below the crown-root boundary. The root lobes are mesiodistally expanded and separated by a well-developed nutrient groove. Remarks: Case and Cappetta (1997) first described Raja farishi from the late Maastrichtian Kemp Clay Formation of Texas and can be differentiated from other Raja species by a crown with a more lingually directed cusp, well-developed transverse edge separating the faces, the lack of a transverse crest, and more separated uvula. The root is also higher, is constricted just below the crown-root boundary, and has mesodistally wider root lobes (Case and Cappetta, 1997; Becker et al. 2004). These characters are clearly apparent in the Peedee specimen. This species is restricted to late Maastrichtian of North America and has been previously reported from the Kemp Clay Formation of Texas, Arkadelphia Formation of Arkansas (Becker et al. 2004), and Severn Formation of Maryland (Hartstein et al. 1999).

$$
\begin{gathered}
\text { Family SCLERORHYNCHIDAE Cappetta, } 1974 \\
\text { Genus Ischyrhiza Leidy, } 1856 \\
\text { Ischyrhiza avonicola Estes, } 1964 \\
\text { Figure 4C }
\end{gathered}
$$

Referred Material: UALVP 57036, incomplete rostral spine.

Description: This is a rostal tooth with a relatively short crown (= cap) that is dorsoventrally compressed towards the apex and is somewhat posteriorly directed. The anterior margin is the convex, whereas the posterior margin is more or less straight. Distinct cutting edges are restricted to the apical half of the crown. The enameloid has considerable damage along the base of the crown but there appears to be a number of short ridges in the undamaged region. The basal region of the large root (= peduncle) is expanded dorsoventrally and forms two short lobes that have a flat basal face.

Remarks: Ischyrhiza avonicola appears to have been a long temporal ranging species that has been reported from numerous Turonian-Maastrichtian deposits within the Western Interior Seaway (e.g., Estes 1964; Cappetta 1973;

Figure 4. Batoid teeth recovered from the late Maastrichtian Peedee Formation at Castle Hayne, New Hanover County, North Carolina. A, Rhinobatos sp. UALVP 57034 (incomplete tooth); B, Raja farishi Case and Cappetta, 1997, UALVP 57035 (complete tooth); C, Ischyrhiza avonicola Estes, 1964, UALVP 57036 (incomplete rostral spine); D, Ischyrhiza mira Leidy, 1856, UALVP 57037 (incomplete rostral spine); E, Sclerorhynchus cf. S. pettersi Case and Cappetta, 1997, UALVP 57038, incomplete rostral spine; F, Ptychotrygon clementsi sp. nov., UALVP 57039 (holotype, complete tooth); G, Ptychotrygon clementsi sp. nov., UALVP 57040 (paratype, complete tooth); H, Dasyatis commercensis Case and Cappetta, 1997, UALVP 57041 (complete tooth); I, Rhombodus binkhorsti Dames, 1881, UALVP 57042 (complete tooth). Views: occlusal for A; occlusal (left), profile (centre), and lingual (right) for B; dorsal (left), posterior (centre), and ventral (right) for C; dorsal (left) and ventral (right) for D; dorsal (left), posterior (right), and ventral (bottom) for E; occlusal (top left), labial (top right), profile (centre), lingual (bottom left), and basal (bottom right) for F and G; occlusal (top left), labial (bottom left), profile (top right), lingual (centre right), and basal (bottom right) for G; occlusal (left), labial (centre left), profile (centre right), lingual (right) for $\mathrm{H}$ and I. Scale bars $=100$ um for $\mathrm{A}-\mathrm{C}$ and $\mathrm{E}-\mathrm{I} ; 1 \mathrm{~mm}$ for $\mathrm{D}$. 


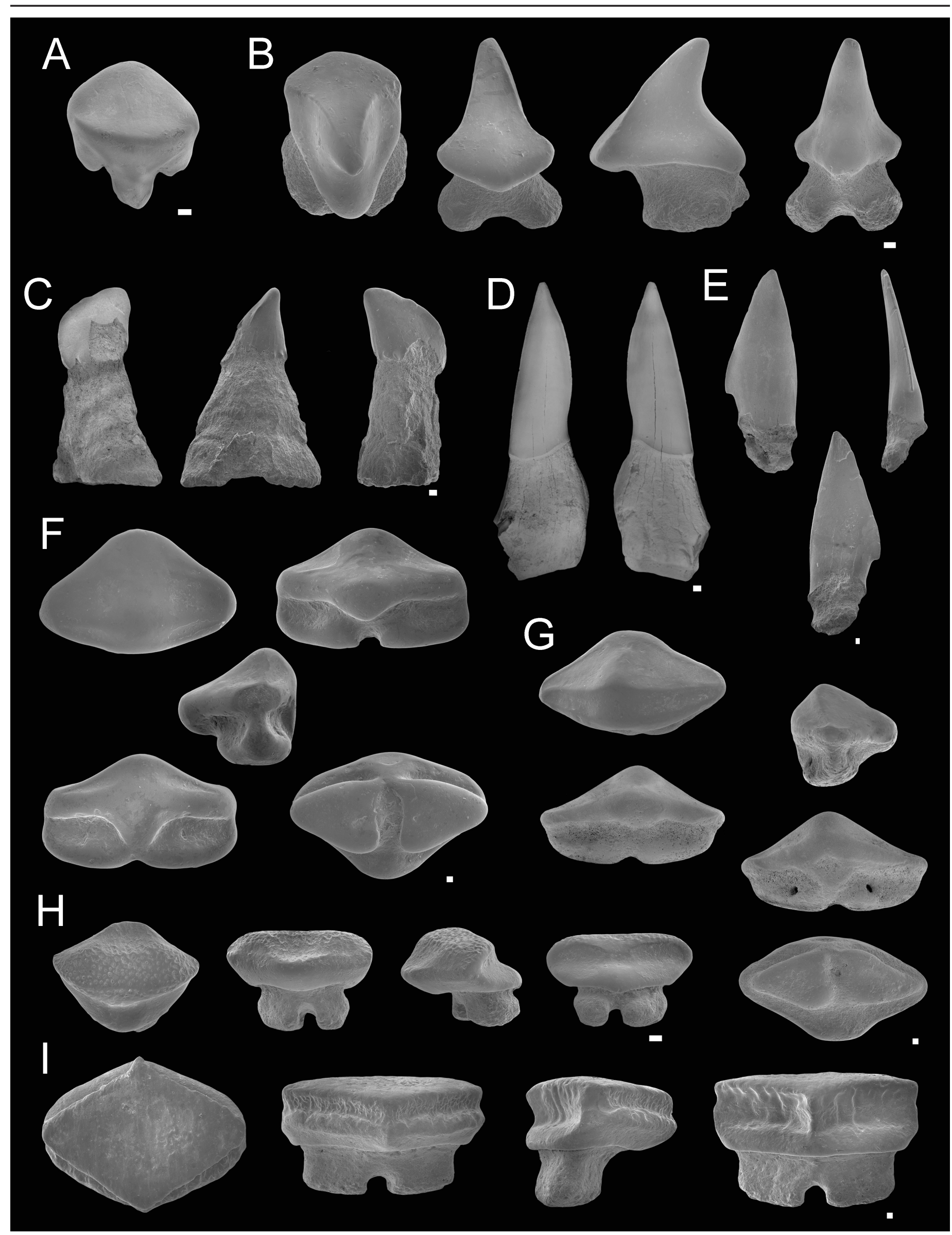


Wolberg 1985; Case 1987; Welton and Farish 1993; Becker et al. 2004; Cook et al. 2014), the Gulf Coast (e.g., Becker et al. 2006) and the Atlantic Gulf plains (e.g., Cappetta and Case 1975; Kent 1994) of North America.

\section{Ischyrhiza mira Leidy, 1856}

Figure 4D

\section{Referred Material: UALVP 57037, incomplete rostral} spine.

Description: This is a rostal spine with a relatively large crown that is slightly dorsoventrally compressed and completely smooth. The anterior margin is more or less straight, whereas the posterior margin is sigmoid. Distinct cutting edges extend from the apex to the base of the crown. The root is large and slightly damaged. The basal region is expanded dorsoventrally and forms two short lobes.

Remarks: Ischyrhiza mira is a relatively common species found in Turonian-Maastrichtian deposits of the Western Interior Seaway (e.g., McNulty and Slaughter 1962; Wolberg 1985; Willamson et al. 1993; Welton and Farish 1993; Case and Cappetta 1997; Beavan and Russell 1999; Becker et al. 2004) and the Atlantic and Gulf Coastal plains (e.g., Cappetta and Case 1975; Case and Schwimmer 1988; Case 1991; Kent 1994; Case et al. 2001; Becker et al. 2004, 2006).

This species was previously reported from the Peedee Formation of Duplin County, North Carolina (Case 1979).

Genus Sclerorhynchus Woodward, 1889 Sclerorhynchus cf. S. pettersi Case and Cappetta, 1997 Figure 4E

Referred Material: UALVP 57038, incomplete rostral spine. Description: This rostal spine has a large smooth crown that is dorsoventrally compressed except at the basal bulge. The anterior margin of the crown is convex and bears a distinct cutting edge that extends from the apex to the base. The convex posterior margin also has a distinct cutting edge that extends from the apex to a well-developed barb. Most of the root is missing.

Remarks: Sclerorhynchus pettersi was first described from the late Maastrichtian of Texas by Case and Cappetta (1997). Subsequently, the species has been reported from the late Maastrichtian New Egypt Formation of New Jersey and Severn Formation of Maryland (Hartstein et al. 1999). Becker et al. (2004) and Becker et al. (2006) reported late Maastrichtian rostral spines identified as Sclerorhynchus sp. from the Fox Hills Formation of South Dakota and Arkadelphia Formation of Arkansas, respectively, and noted their morphological resemblance to $S$. pettersi.
Family PTYCHOTRYGONIDAE Kriwet, Nunn, and Klug, 2009

Genus Ptychotrygon Jaekel, 1894

Ptychotrygon clementsi sp. nov. Figure $4 \mathrm{~F}$ and $\mathrm{G}$ urn:lsid:zoobank.org:act:BD372690-DDC8-48BDADC1-FB6E9E0A6F8B

Holotype: UALVP 57039 (holotype), complete tooth of indeterminate jaw position.

Paratype: UALVP 57040 (paratype), complete tooth of indeterminate jaw position.

Diagnosis: Mesodistally elongated teeth with a distinct labial visor and broad apron that overhangs the root, a well-developed uvulae with a central depression, and a crown possessing a blunt transverse crest and lacks any ornamentation.

Type Locality and Horizon: Island Creek Member of the Peedee Formation.

Etymology: Named in honour of Don Clements for his work on North Carolina geology.

Description: These teeth are mesiodistally elongated and possesses a high crown with a rather weak dome-like cusp that is lingually positioned. A blunt transverse ridge separates the labial crown face from the lingual face. The labial face is smooth and has a well-developed labial visor and broad apron that overhangs the upper half of the root. The lingual crown face also lacks ornamentation and possesses a distinct median lingual uvula that bears a weak central depression. The root is mesiodistally expanded. A shallow nutrient groove bearing a central foramen separates the two large lobes that are triangular in nature. The basal face is flat. Additional large foramina are situated on the margino-lingual root faces.

Remarks: Kriwet et al. (2009) noted that the ptychotrygonids can be distinguished from other sclerorhynchiforms by the presence of a transverse crest and a distinct labial visor. Ptychotrygon is a rather speciose taxon that has been reported from Albian - Maastrichtian deposits of Europe, northern Africa, and North America (Kriwet et al. 2009; Cappetta 2012). North American Campanian and Maastrichtian species include P. blainensis Case, 1978 from the Judith River Formation of Montana, $P$. boothi Case, 1987, P. ellae Case, 1987 and P. greybullensis Case, 1987 from the Mesaverde Formation of Wyoming, P. vermiculata Cappetta, 1975b from the Mount Laurel Formation of New Jersey, and P. winni Case and Cappetta, 1997 and P. texana (Leriche, 1940) from the Kemp Clay Formation and P. agujaensis McNulty and Slaughter, 1972 from the Aguja Formation of Texas. Although possessing a distinct visor and apron, a uvula 
with a central depression and an overall contour similar to that of Ptychotrygon spp. mentioned above, P. clementsi sp. nov. can be readily differentiated by its rather weak transverse ridge and lack of distinct crown ornamentation.

\section{Order MYLIOBATIFORMES Compango, 1973 \\ Family DASYATIDAE Jordan, 1888 \\ Genus Dasyatis Rafinesque, 1810 \\ Dasyatis commercensis Case and Cappetta, 1997}

Figure $4 \mathrm{H}$

Referred Material: UALVP 57041, complete tooth of indeterminate jaw position.

Description: This tooth has a crown possessing a blunt transverse ridge that separates the labial and lingual faces. The labial face is convex, whereas the lingual face is concaved in profile view. Distinct alveolar ornamentation is restricted to the labial face. The labial visor overhangs the root and is convex. The smooth lingual face is divided by a weak median lingual ridge and possesses a well-developed visor. The root is positioned lingually under the crown. A deep nutrient groove separates the root lobes and bears a central foramen.

Remarks: Case and Cappetta (1997) originally described Dasyatis commercensis from the late Maastrichtian Clay Kemp Formation of Texas and noted that this species can be differentiated from other Late Cretaceous taxa by its relatively broad labial visor and the pitted crown ornamentation. Teeth identified as Dasyatis sp. from the Arkadelphia Formation of Arkansas by Becker et al. (2006) has an overall morphology similar to that of the type material and Peedee specimen.

\section{Family RHOMBODONTIDAE Cappetta, 1987 Genus Rhombodus Dames, 1881 Rhombodus binkhorsti Dames, 1881}

Figure 4I

Referred Material: UALVP 57042, complete tooth of indeterminate jaw position.

Description: This tooth has a robust crown that is rhombic in occlusal view. In profile view, the flat occlusal surface is somewhat inclined lingually. The margino-labial and margino-lingual faces are slightly concave and bear distinct vertical enameloid folding. A weak lingual bulge is present. The root is positioned under the lingual region of the crown. The root lobes are divided by a well-developed nutrient groove containing several nutrient foramina.

Remarks: Rhombodus binkhorsti is a wide ranging species that has been reported from Maastrichtian deposits of Europe, northern and western Africa, and South America
(Cappetta 2012; Corral et al. 2016 and references therein). North American reports include Western Interior Seaway (Welton and Farish 1993; Case and Cappetta 1997) and the Atlantic and Gulf Coastal plains (Case et al. 2001; Becker et al. 2006). This species was previously reported from the Peedee Formation of Duplin County, North Carolina by Case (1979, as Rhombodus cf. R. binkhorsti).

\section{DISCUSSION}

This inner neritic assemblage described herein includes 23 species from 20 genera, 17 families and eight orders of selachians, with the description of the new species Ptychotrygon clementsi sp. nov. Additionally, Case (1979) reported Hybodus sp., Scapanorhynchus texanus (Roemer, 1849), and Archaeolamna kopingensis (Davis, 1890) from the Pee Dee Formation, exposed in Duplin County, North Carolina. It should be noted that the tooth figured as Odontaspis sp. by Case (1979: figs. 13 and 14) bears a strong resemblance to that of Carcharias sambammeri.

Species (and those that compare favourably) from the Peedee assemblage that appear endemic to the southern Western Interior Seaway (e.g., Welton and Farish 1993; Case and Cappetta 1997), Gulf Coastal (e.g., Becker et al. 2006) and Atlantic Coastal plains (e.g., Cappetta and Case 1975; Case 1979; Kent 1994) include Squalus huntensis, Heterdontus granti, Cantioscyllium meyeri, Plicatoscyllium derameei, Raja farishi, Dasyatis commercensis and the new species Ptychotrygon clementsi. Those species that have an expanded distribution into the northern regions of the Western Interior Seaway (e.g., Beavan and Russell 1999; Becker et al. 2004; Cook et al. 2014) include Carcharias samhammeri, Odontaspis aculeatus, Ischyrhiza avonicola, I. mira, and Sclerorhynchus pettersi. The morphology of the recovered Palaeogaleus tooth is somewhat different from that of European species and it may represent an endemic taxon of North America. Further supporting this notion is the rather limited palaeobiogeographic range of the congeneric taxa (see Cappetta 2012).

Cosmopolitan species from the Peedee assemblage that have been reported from deposits outside of North America include Notidanodon sp., Cretalamna maroccana, Squlicorax kaupi, Squlicorax pristodontus, Pseudocorax affinis, Serratolamna serrata, and Rhombodus binkhorsti. As mentioned previously, the recovered Notidanodon teeth are heavily damaged but do resemble that of the widely distributed species Notidanodon dentatus. Also noted above was the questionable occurrence of Plicatoscyllium antiquum from Angola (Antunes and Cappetta 2002). Despite being demersal, many extant ginglymostomatid species have rather wide biogeographical ranges (Musick et al. 2004). The occurrence of the late Maastrichtian species P. lehneri (Leriche, 1938) from multiple deposits on both sides of 
the Atlantic seems to corroborate this notion (Corral et al. 2016). Therefore, it is plausible that $P$. antiquum frequented both western African and southeastern North American waters. The report of Anomotodon toddi from the late Santonian of Jordan (Mustafa 2000) is also suspect given subtle differences in tooth morphology and likely represents a new species. The limited distribution of Palaeogene species [e.g., A. sheppeyensis (Casier, 1966), A. novus (Winkler, 1876), and A. cravenensis (Case, 1980)] appears to support the opinion herein that $A$. toddi was endemic to North American waters. The occurrence of Squalicorax, Cretalamna, and Serratolamna in the Peedee assemblage is not surprising as Corral et al. (2016: p. 658) noted that these pelagic taxa migrated across the Proto-Atlantic "favoured by ocean currents, according to their global distribution". They also note that the benthic Rhombodus binkhorsti may have attained its circumtropical distribution by means of "transoceanic migration by swimming along the shelf from western Africa to South America." A northern expansion of this species from South America into the southern region of the Western Interior Seaway and the Atlantic and Gulf Coastal plains is not unlikely. Finally, the occurrence of Hybodus, Scapanorhynchus texanus, and Archaeolamna kopingensis from the Peedee Formation exposed in Duplin County, North Carolina are also reported from continents outside of North America (e.g., Biddle 1993; Siverson 1992; Mustafa 2000; Zalmout and Mustafa 2001; Antunes and Cappetta 2002; Cappetta 2012; Guinot et al 2013; Vullo and Courville 2014).

\section{ACKNOWLEDGEMENTS}

We would like to thank Donald Clements for assisting in the collection the Peedee assemblage and for providing stratigraphic photographs and geological insights. We also are grateful to the owners and employees of the MartinMarietta Castle Hayne Quarry (New Hanover County, North Carolina) that permitted access to the quarry for specimen collection. We also extend their gratitude to the staff at the Scanning Electron Microscope Laboratory (Department of Earth and Atmospheric Sciences, University of Alberta), Jessica Yee for assistance with specimen imaging and Michelle Templin for French translation of key references. Comments by Jorge D. Carrillo-Briceño (University of Zurich), an anonymus reviewer, and editor Alison Murray (University of Alberta) greatly improved the manuscript. This project was supported by NSERC Discovery Grant 327448 to Alison M. Murray (University of Alberta).

\section{LITERATURE CITED}

Adolfssen, J. and D.J. Ward. 2014. Crossing the boundary: an elasmobranch fauna from Stevns Klint, Denmark. Palaeontology 57:591-629. DOI: 10.1111/pala.12079.

Agassiz, J.L.R. 1833-1844. Recherches sur les poissons fossils, 3. Imprimerie de Petitpierre, Neuchâtel, 1420 pp.

Albers, H. and W. Weiler. 1964. Eine Fischfauna aus der oberen Kreide von Aachen und neuere Funde von Fischresten aus dem Maestricht des angrenzenden belgisch-holländischen Raumes. Neues Jahrbuch für Geologie und Paläontologie, Abhandlungen, 120:1-33.

Antunes, M.T. 1964. Neocretácio e o Cenozóico do Litoral de Angola. Junta de Investigaçôes do Ultramar, Lisboa, 254 pp.

Antunes, M.T. and H. Cappetta. 2002. Sélaciens du Crétacé (Albien-Maastrichtien) d'Angola. Palaeontographica, Abt. A 264: 85-146.

Applegate, S.P. 1965. A confirmation of the validity of Notorhynchus pectinatus; the second record of this Upper Cretaceous Cowshark. Bulletin of the Southern California Academy of Sciences, 64:122-126.

Applegate, S.P. 1972. A revision of the higher taxa of orectolobids. Journal of the Marine Biology Association of India. 14:743-751.

Arambourg, C. 1935. Note préliminaire sur les vertébrés fossiles des phosphates du Maroc. Bulletin de la Société Géologique de France 5:413-439.

Arambourg, C. 1952. Les vertébrés fossiles des gisements de phosphates (Maroc, Algérie, Tunisie). Notes et Mémoires du Service Géologique, Maroc 92:13-72.

Bardet, N., H. Cappetta, X. Pereda Suberbiola, M. Mouty, A.K. Al-Maleh, A.M. Ahmad, O. Khrata and N. Gannoum. 2000. The marine vertebrate faunas from the Late Cretaceous phosphates of Syria. Geological Magazine 137:269-290.

Beavan, N.R. and A.P. Russell. 1999. An elasmobranch assemblage from the terrestrial-marine transitional Lethbridge Coal Zone (Dinosaur Park Formation: Upper Campanian), Alberta, Canada. Journal of Paleontology 73:494-503.

Becker, M.A., J.A. Chamberlain and D.O. Terry. 2004. Chondrichthyans from the Fairpoint Member of the Fox Hills Formation (Maastrichtian), Meade County, South Dakota. Journal of Vertebrate Paleontology 24:780-793.

Becker, M.A., J.A. Chamberlain and G.E. Wolf. 2006. Chondrichthyans from the Arkadelphia Formation (Upper Cretaceous: upper Maastrichtian) of Hot Spring County, Arkansas. Journal of Paleontology 80:700-716. DOI: 10.1671/0272-4634(2004)024[0780:CFTFMO]2.0.CO;2

Berg, L.S. 1937. A classification of fish-like vertebrates. Bulletin de l'Académie des Sciences de l'URSS. Classe des Sciences Mathématiques et Naturelles 1937:1277-1280.

Berg, L.S. 1958. System der Rezenten und Fossilen Fischartigen und Fische. Hochschulbücher für Biologie, Berlin, 310 pp.

Biddle, J.P. 1993. Les Elasmobranches de l'Albien inférieur et moyen (Crétacé inférieur) de la Marne et de la Haute-Marne 
(France). Belgian Geological Survey, Professional Paper: Elasmobranches et Stratigraphie 264:191-240.

Blainville, H.M.D. de. 1816. Prodom d'une novella distribution systématique du règne animal. Bulletin de la Société Philomáthique, Paris 8:113-124.

Bogan, S., F.L. Agnolin and F.E. Novas. 2016. New selachian records from the Upper Cretaceous of southern Patagonia: paleobiogeographical implications and the description of a new taxon. Journal of Vertebrate Paleontology. DOI:10.1080/02724 634.2016.1105235.

Bonaparte, C.L. 1834. Iconografia della fauna italic per le Quattro classi degli animali vertebrati. Tomo III. Pesci. Rome: Tip Salviucci.

Bonaparte, C.L. 1838. Selachorum tabula analytica. Nuovi Annali della Scienze Naturali, Bologna 1:195-214.

Bourdon, J., K. Wright, S.G. Lucas, J.A. Spielman and R. Pence. 2011. Selachians from the Upper Cretaceous (Santonian) Hosta Tongue of the Point Lookout Sandstone, central New Mexico. New Mexico Museum of Natural History and Science, Bulletin 52:1-52.

Buen, F. 1926. Catalogo ictiologico del Mediterraneo Español y de Marruecos, recopilando lo publicado sobrepeces de las costas mediterraneas y proximas del Atlantico (Mar de España). Resultados de las ampafias Realizadas por Acuerdos Internacionales. Instituto Espańol de Oceanografia 2:1-221.

Cappetta, H. 1973. Selachians from the Carlile Shale (Turonian) of South Dakota. Journal of Paleontology 47:504-514.

Cappetta, H. 1974. Sclerorhynchidae nov. fam., Pristidae et Pristiophoridae: un exemple de parallélisme chez les Sélaciens. Comptes Rendus hebdomadaires des séances de l'Academie des Sciences 278:225-228.

Cappetta, H. 1975a. Les Sélaciens éocènes du Monte-Bolca. I Les Carcharhinidae. Miscellanea Paleontologica. Studi e ricerche sui giacimenti Terziari di Bolca 2:279-305.

Cappetta, H. 1975b. Ptychotrygon vermiculata nov. sp., sélacien nouveau du Campanien du New Jersey (U.S.A.). Compte Rendu sommaire des Société Géologique de France 5:164-166.

Cappetta, H. 1980. Les sélaciens du Crétacés superieur du Liban: Battoides. Palaeontographica, Abt. A 168:149-229.

Cappetta, H. 1987. Handbook of Paleoichthyology, Vol. 3B: Chondrichthyes II. Gustav Fischer Verlag, Stuttgart.

Cappetta, H. 2012. Chondrichthyes. Mesozoic and Cenozoic Elasmobranchii: Teeth. Handbook of Palaeoichthyology, Volume 3E. München: Verlag Dr. Friedrich Pfeil.

Cappetta, H. and G.R. Case. 1975. Contribution à l'étude des Sélaciens du groupe Monmouth (Campanien-Maestrichtien) du New Jersey. Palaeontographica, Abt. A, 151:1-46.

Cappetta, H. and G.R. Case. 1999. Additions aux faunes de sélaciens du Crétacé du Texas (Albien supérieur-Campanien). Palaeo Ichthyologica 9:5-111.

Cappetta, H. and G.S. Odin. 2001. Les sélaciens du CampanienMaastrichtien de Tercis-les-Bains (SO France). Developments in Palaeontology and Stratigraphy 19:645-651. DOI: 10.1016/ S0920-5446(01)80059-5
Cappetta, H., N. Bardet, X. Pereda Suberbiola, S. Adnet, D. Amalik, M. Amalik and A. Benabdallah. 2014. Marine vertebrate faunas from the Maastrichtian phosphates of Benguérir (Ganntour Basin, Morocco): Biostratigraphy, palaeobiogeography and palaeoecology. Palaeogeography, Palaeoclimatology, Palaeoecology 409:217-238.

DOI: $10.1016 /$ j.palaeo.2014.04.020

Case, G.R. 1978. A new selachian fauna from the Judith River Formation (Campanian) of Montana. Palaeontographica, Abt. A, 160:176-205.

Case, G.R. 1979. Cretaceous selachians from the Peedee Formation (Late Maastrichtian) of Duplin Country, North Carolina. Brimleyana 2:77-89.

Case, G.R. 1980. A selachian fauna from the Trent Formation, Lower Miocene (Aquitanian) of Eastern North Carolina. Palaeontographica, Abt. A, 171:75-103.

Case, G.R. 1981. Late Eocene selachians from South-central Georgia. Palaeontographica, Abt. A 176:52-79.

Case, G.R. 1987. A new selachian fauna from the Late Campanian of Wyoming (Teapot Sandstone Member, Mesaverde Formation, Big Horn Basin). Palaeontographica, Abt. A 197:1-37.

Case, G.R. 1991. Selachians (sharks) from the Tupelo Tongue of the Coffee Sands (Campanian, Upper Cretaceous) in northern Lee County, Mississippi. Mississippi Geology, 11:1-8.

Case, G.R. 1994. Fossil fish remains from the late Paleocene Tuscahoma and early Eocene Bashi Formations of Meridian, Lauderdale County, Mississippi. Part I. Selachians.

Palaeontographica, Abt. A 230:97-138.

Case, G.R. 1995. Fossil shark remains from the early and middle Maastrichtian of the Upper Cretaceous of Monmouth County, New Jersey. Pp. 72-80 in J. Baker (ed). Contributions to the Paleontology of New Jersey. Geological Association of New Jersey.

Case, G.R. and D.R. Schwimmer. 1988. Late Cretaceous fish from the Blufftown Formation (Campanian) in western Georgia. Journal of Paleontology 62:290-301.

Case, G.R. and H. Cappetta. 1997. A new selachian fauna from the Late Maastrichtian of Texas (Upper Cretaceous/Navarroan; Kemp Formation). Müenchner Geowissenschaftliche Abhandlungen Reihe A Geologie und Paläeontologie 34:131-189.

Case, G.R. and H. Cappetta. 2004. Additions to the elasmobranch fauna from the late Cretaceous of New Jersey (lower Navesink Formation, early Maastrichtian). Palaeovertebrata 33:1-16.

Case, G.R., P.D. Borodin and J.J. Leggett. 2001. Fossil selachians from the New Egypt Formation (Upper Cretaceous, Late Maastrichtian) of Arneytown, Monmouth County, New Jersey. Palaeontographica, Abt. A, 261:113-124.

Case, G.R., T.D. Cook and M.V.H. Wilson. 2015. A new elasmobranch assemblage from the early Eocene (Ypresian) Fishburne Formation of Berkeley County, South Carolina, USA. Canadian Journal of Earth Sciences 52:1121-1136. DOI: 10.1139/cjes-2015-0061. 
Casier, E. 1947. Constitution et évolution de la racine dentaire des Euselachii. II. Etude comparative des types. Bulletin du Musée Royal d'Histoire Naturelle de Belgique 23:1-32.

Casier, E. 1966. Sur la faune ichthyologique de la Formation de Bissex Hill et de la Série océanique, de l'Ile de la Barbade, et sur l'âge de ces formations. Eclogae Geologicae Helvetiae, 59:493-516.

Cicimurri D. 2007. A late Campanian (Cretaceous) selachian assemblage from a classic locality in Florence County, South Carolina. Southeast Geology, 45:59-72.

Cinoe, A.L. and F.A. Medina. 1987. A record of Notidanodon pectinatus (Chondrichthyes, Hexanchiformes) in the Upper Cretaceous of the Antarctic Peninsula. Mesozoic Research, 1:79-88.

Compagno, L.J.V. 1973. Interrelationships of living elasmobranchs. Pp. 15-61 in P.H. Greenwood, R.S. Miles and C. Patterson. Interrelationships of Fishes. Zoological Journal of the Linnean Society 53.

Compagno, L.J.V. 1977. Phyletic relationships of living sharks and rays. American Zoologist 17:303-322.

Cook, T.D., M.G. Newbrey, D.B. Brinkman and J.I Kirkland. 2014. Euselachians from the freshwater deposits of the Hell Creek Formation of Montana. Geological Society of America, Special Paper, 503:229-246. DOI: 10.1130/2014.2503(08).

Corral, J.C., A. Berreteaga and H. Cappetta. 2016. Upper Maastrichtian shallow marine environments and neoselachian assemblages in North Iberian palaeomargin (Castilian Ramp, Spain). Cretaceous Research 57:639-661. DOI: 10.1016/j. cretres.2015.08.001.

Cuny, G., J.E. Martin and R. Sarr. 2012. A neoselachian shark fauna from the Late Cretaceous of Senegal. Cretaceous Research, 34:107-115. DOI: 10.1016/j.cretres.2011.10.008.

Dames, W. 1881. Über Fischzähne aus der obersenonen Tuffkreide von Maastricht für welcher den Gattungsnamen Rhombodus vorschlug. Sitzungsberichte der Gesellschaft naturforschender Freunde zu Berlin 1881:1-3.

Dartevelle, E., and Casier, E. 1943. Les poissons fossiles du BasCongo et des régions voisines. Annales du Musée du Congo Belge, Sér. A (Minéralogie, Géologie, Paléontologie) 3, 2:1-200.

Davis, J.W. 1888. On fossil fish-remains from the Tertiary and Cretaceo-Tertiary formations of New-Zealand. Scientific Transactions of the Royal Dublin Society 4:1-48.

Davis, J.W. 1890. On the fossil fish of the Cretaceous formations of Scandinavia. Scientific Transactions of the Royal Dublin Society, 2:363-434.

Dockal, J.A., W.B. Harris and R.A. Laws. 1998. Late Maastrichtian sediments on the north flank of the Cape Fear Arch, North Carolina. Southeastern Geology 37:149-159.

Estes, R. 1964. Fossil vertebrates from the Late Cretaceous Lance Formation, eastern Wyoming. University of California Publications in Geological Sciences 49:1-180.

Gill, T.N. 1862. Analytical synopsis of the Order of Squali and revision of the nomenclature of the genera. Annals of the Lyceum of Natural History of New York 7:367-408.
Glikman, L.S. 1958. Rates of evolution in lamnoid sharks. Doklady Akademij Nauk SSSR 123:568-571. [In Russian].

Glikman, L.S. 1964. Sharks of Paleogene and their stratigraphic significance. Moscow: Nauka Press. [In Russian]

Goodrich, 1909. Vertebrata Craniata. I. Cyclostomes and Fishes. A Treatise on Zoology, Part 9. London: Adam and Charles Black, 518 pp.

Gottfried, M.D., J.A. Rabarison and L.L. Randriamiarimanana. 2001. Late Cretaceous elasmobranchs from the Mahajanga Basin of Madagascar. Cretaceous Research 22:491-496. DOI: 10.1016/j.cretres.2008.09.003.

Gray, J.E. 1851. List of the Specimens of Fish in the Collection of the British Museum. Part I. Chondropterygii. British Museum (Natural History), London, 160 pp.

Guinot, G., C.J. Underwood, H. Cappetta, H. and D.J. Ward. 2013. Sharks (Elasmobranchii: Euselachii) from the Late Cretaceous of France and the UK. Journal of Systematic Palaeontology 11:589-671.

Gurr, P.R. 1962. A new fish fauna from the Woolwich Bottom Beds (Sparnacian) of Herne Bay, Kent. Proceedings of the Geologists' Association 73:419-447.

Harris, W.B. and J.M Self-Trail. 2006. Late Cretaceous base level lowering in Campanian and Maastrichtian depositional sequences, Kure Beach, North Carolina. Stratigraphy 3:195-216.

Hartstein, E., L. Decina and R. Keil. 1999. A Late Cretaceous (Severn Formation) vertebrate assemblage from Bowie Maryland. Mosasaur 6:17-24.

Hay, O.P. 1902. Bibliography and catalogue of the fossil Vertebrata in North America. United States Geological Survey Bulletin 179:1-868.

Herman, J. 1977. Les Sélaciens des terrains néocrétacés et paléocènes de Belgique et des contrées limitrophes. Eléments d'une biostratigraphie intercontinentale. Mémoires pour servir à l'explication des Cartes géologiques et minières de la Belgique, 15:1-401.

Hoganson, J.W. and E.C. Murphy. 2002. Marine Breien Member (Maastrichtian) of the Hell Creek Formation in North Dakota: Stratigraphy, vertebrate fossil record, and age. Geological Society of America, Special Paper 361:247-269.

Huxley, T.H. 1880. On the application of the laws of evolution to the arrangement of the Vertebrata and more particularly of the Mammalia. Proceedings of the Zoological Society of London 1880:649-662.

Jaekel, O. 1894. Die eocänen Selachier vom Monte Bolca.

Jordan, D. S. 1888. A Manual of Vertebrate Animals of the Northern United States, Including the District North and East of the Ozark Mountains, South of the Laurentian Hills, North of Virginia, and East of the Missouri River, Inclusive of Marine Species, Fifth Edition. Chicago, 375 pp.

Jordan, D.S. 1898. Description of a species of fish (Mitsukurina owstoni) from Japan, the type of a distinct family of lamnoid sharks. Proceedings of the California Academy of Sciences, (Series 3, Zoology) 1:199-202. 
Kent, B.W. 1994. Fossil Sharks of the Chesapeake Bay Region. Columbia, MD. Egan Rees and Boyer, Inc., 146 pp.

Kriwet J. 1999. Neoselachier (Pisces, Elasmobranchii) aus der Unterkreide (unteres Barremium) von Galve und Alciane (Spainien, Provinz Teruel). Palaeo Icthyologica 9:113-143.

Kriwet, J., E.V. Nunn S. and Klug. 2009. Neoselachians (Chondrichthyes, Elasmobranchii) from the Lower and lower Upper Cretaceous of north-eastern Spain. Zoological Journal of the Linnean Society 155:316-347.

Landemaine, O. 1991. Sélaciens nouveaux du Crétacé supérieur du Sud-Ouest de la France. Quelques rapports à la systématique des élasmobranches. Société Amicale des Géologues Amateurs 1:1-45.

Leidy, J. 1856. Notice of remains of extinct vertebrate animals of New Jersey, collected by Prof. Cook of the State Geological Survey under the direction of Dr. W. Kitchel. Proceedings of the Academy of Natural Sciences of Philadelphia 8:220-221.

Leriche, M. 1938. Contribution à l'étude des poissons fossiles des pays riverains de la Méditerranée américaine (Vénézuéla, Trinité, Antilles, Mexique). Mémoires de la Société Paléontologique Suisse, 61:1-42.

Lewy, Z. and H. Cappetta. 1989. Senonian elasmobranch teeth from Israel. Biostratigraphic and paleoenvironmental implications. Neues Jahrbuch für Geologie und Palaontologie, Monatshefte, 1989:212-222.

Linck, H.F. 1790. Versuch einer Eintheilung der Fische nach den Zähnen. Magazin für das Neueste aus der Physik und Naturgeschichte 6:28-38.

Linnaeus, C. 1758. Systema Naturae per regna tria naturae, regnum animale, secundum classes, ordines, genera, species, cum characteribus differentiis synonymis, locis. Ed. X., Stockholm.

Martin, J.E. and J.A. Crame. 2006. Paleobiological significance of high-latitude Late Cretaceous vertebrate fossils from the James Ross Basin, Antarctica. Pp. 109-124 in J.E. Francis, D. Pirrie and J.A. Crame (eds). Cretaceous-Tertiary High-Latitude Paleoenvironments, James Ross Basin, Antarctica: Geological Society of London, Special Publication.

McNulty, C.L. and B.H. Slaughter. 1962. A new sawfish from the Woodbine Formation (Cretaceous) of Texas. Copeia, 1962:775-717.

Müller, J., and Henle, F.G.J. 1838-1841. Systematische Beschreibung der Plagiostomen. Berlin, 204 pp.

Musick, J.A., M.M Harbin and L.J.V. Compagno. 2004. Historical zoogeography of the Selachii. Pp. 33-78 in J.C. Carrier, J.A. and M.R. Heithaus (eds). Biology of Sharks and their Relatives, Fl: CRC Press LLC.

Mustafa, H.A. 2000. Fish teeth from the upper Umm Ghudran Formation (late Santonian) of NW-Jordan. Neues Jahrbuch für Geologie und Paläontologie, Monatshefte 2000:595-612.

Noubhani, A. and H. Cappetta. 1997. Les Orectolobiformes, Carcharhiniformes et Myliobatiformes (Elasmobranchii, Neoselachii) des bassins à phosphate du Maroc (MaastrichtienLutétien basal). Systématique, biostratigraphie, évolution et dynamique des faunes. Palaeo Ichthyologica 8:1-327.
Parmley, D. and D.J. Cicimurri. 2003. Late Eocene sharks of the Hardie Mine local fauna of Wilkinson County, Georgia. Georgia Journal of Science 61:153-179.

Priem, F. 1897. Sur des dents d'élasmobranches de divers gisments sénoniens (Villedieu, Meudon, Folx-les-Caves). Bulletin de la Societe Geologique de France 25:40-56.

Rafinesque, C.S. 1810. Caratteri di alcuni nuovi generi e nuove specie di animali e piante della Sicilia, con varie osservazioni sopra I medisimi. Palermo (Sanfilippo), 105 pp.

Roemer, C.F. 1849. Texas: Mit besonderer Rücksicht auf deutsche Auswanderung und die physischen Verhältnisse des Landes. Mit einem naturwissenschaftlichen Anhange und einer topographisch-geognostischen Karte von Texas.

Shimada, K., and D.J. Cicimurri. 2006. The oldest record of the Late Cretaceous anacoracid shark, Squalicorax pristodontus (Agassiz), from the Western Interior, with comments on Squalicorax phylogeny. New Mexico Museum of Natural History and Science, Bulletin 35:177-184.

Shimada, K., and D.D. Brereton. 2007. The Late Cretaceous lamniform shark, Serratolamna serrata (Agassiz), from the Mooreville Chalk of Alabama. Paludicola 6:105-110.

Siverson, M. 1992. Biology, dental morphology and taxonomy of lamniform sharks from the Campanian of the Kristianstad Basin, Sweden. Palaeontology 35:519-554.

Underwood, C.J., and S.F. Mitchell. 2000. Serratolamna serrata (Agassiz) (Pisces, Neoselachii) from the Maastrichtian (Late Cretaceous) of Jamaica. Caribbean Journal of Earth Science 34:25-30.

Underwood, C.J. and Ward, D. 2008. A review of the Mesozoic record of the Carcharhiniformes. Pp. 433-442 in G. Arratia (ed.) Mesozoic Fishes: Homology and Phylogeny. Mesozoic Fishes 4. Munich, Germany: Verlag Dr. Friedrich.

Van de Geyn, W. 1937. Les élasmobranches du Crétacé marin du Limbourg Hollandais. Natuurhistorisch Maandblad Maestricht, 26: 16-21, 28-33, 42-53, 56-60, 66-69.

Vega, F.J., G.E. Phillips, T. Nyborg, J. Flores-Ventura, D. Clements, B. Espinosa and G. Solís-Pichardo. 2013, Morphology and size variation of a portunoid crab from the Maastrichtian of the Americas. Journal of South American Earth Sciences 47:1-20.

Vullo, R. and P. Courville. 2014. Fish remains (Elasmobranchii, Actinopterygii) from the Late Cretaceous of the Benue Trough, Nigeria. Journal of African Earth Sciences 97:194-206. DOI: 10.1016/j.jafrearsci.2014.04.016.

Ward, D.J. and R.L. Wiest. 1990. A checklist of Palaeocene and Eocene sharks and rays (Chondrichthyes) from the Pamunkey Group, Maryland and Virginia, USA. Tertiary Research 12:81-88.

Welton, B.J. and R.F. Farish. 1993. The Collector's Guide to Fossil Sharks and Rays from the Cretatceous of Texas. Lewisville, TX: Before Time, 204 pp.

Whitley, G.P. 1939. Taxonomic notes on sharks and rays. Australian Zoologist 9:227-262. 
Williamson, T.E., J.I. Kirkland and S.G. Lucas. 1993. Selachians from the Greenhorn cyclothem ("middle" Cretaceous: Cenomanian-Turonian), Black Mesa, Arizona, and the paleogeographic distribution of Late Cretaceous selachians. Journal of Paleontology 67:447-474.

Winkler, T.C. 1876. Mémoire sur quelques restes de poisons du système heersien. Archives du Musée Teyler 4:1-15.

Wolberg, D. 1985. Selachians from the Late Cretaceous (Turonian) Atarque Sandstone Member, Tres Hermanos Formation, Sevilleta Grant, Socorro County, New Mexico. New Mexico Geology 7:1-7.

Woodward, A.S. 1886. On the palaeontology of the selachian genus Notidanus Cuvier. Geological Magazine 3:205-217.

Woodward, A.S. 1889. Catalogue of the Fossil Fishes in the British Museum. Part. I. British Museum (Natural History), London, 378 pp.

Woodward, A.S. 1911. The fossil fishes of the English Chalk. Part VI. Monograph of the Palaeontographical Society London 64:185-224.

Zalmout, I.S. and H.A. Mustafa. 2001. A selachian fauna from the Late Cretaceous of Jordan. Abhath Al-Yamouk Basic Sciences and Engineering 10:374-434. 